\title{
Effects of dexamethasone on the growth of cultured rabbit articular chondrocytes:relation with the nuclear glucocorticoid-receptor complex
}

\author{
BERNARD HAINQUE, JOCELYNE DOMINICE, PATRICK JAFFRAY, \\ XAVIER RONOT, AND MONIQUE ADOLPHE
}

From the Laboratoire de Pharmacologie Cellulaire de l'École Pratique des Hautes Études, Institut Biomédical des Cordeliers, 15 Rue de l'École de Médecine, 75006 Paris, France

SUMmaRY This study reports that dexamethasone at a high dose $\left(10^{-4} \mathrm{~mol} / \mathrm{l}\right)$ induced slowing of the in vitro proliferation of rabbit articular chondrocytes in both monolayer and clonal culture. $\vec{P}$ This effect is consistent with an inhibition of DNA and RNA synthesis and was characterised by? an accumulation of cells in the $\mathrm{G}_{0} \mathrm{G}_{1}$ phase of the cell cycle, as shown by flow cytometric analysis. Therefore we determined the extent of nuclear localisation of dexamethasone-receptor complexes. The results showed a discrepancy between $50 \%$ growth inhibitory dose $\left(10^{-4} \mathrm{~mol} / \mathrm{l}\right) \frac{\mathbb{Q}}{\mathcal{O}}$ and the apparent affinity, $K_{D}\left(1.4(S D 0.2) \times 10^{-9} \mathrm{~mol} / \mathrm{l}\right)$. Thus the growth inhibition of rabbit articular chondrocytes by dexamethasone did not seem to be related exclusively to an interaction with the glucocorticoid-receptor complexes.

Key words: cartilaginous cell culture, cell proliferation, flow cytometry, anti-inflammatory drue binding.

The extensive use of glucocorticoids in the therapy of articular inflammatory diseases is due, in a large part, to their anti-inflammatory, immunosuppressive and antiallergic properties. The activity of these molecules is unfortunately associated with adverse effects, sometimes toxic, which result from these same pharmacological properties. Clinical trials have shown that locally injected glucocorticoids may have a beneficial effect on the course of rheumatoid arthritis. Repeated injections of corticosteroids, however, seem to lead to progressive joint destruction.' During the inflammatory process many complex interactions have been observed with different immunocompetent cells containing various targets for the glucocorticoids. Their catabolic effect generally results in an inhibition of cellular growth, which might even induce cellular lysis. It appears that the glucocorticoids act directly at the level of regulatory mechanisms for cellular proliferation. Two opposite effects have been shown: firstly, an inhibitory effect on various cell types ${ }^{2-11}$ and

Accepted for publication 11 July 1986.

Correspondence to $\mathrm{Dr}$ Bernard Hainque, Laboratoire de Pharmacologie Cellulaire de l'École Pratique des Hautes Études, Institut Biomédical des Cordeliers, 15 Rue de l'École de Médecine, 75006 Paris, France. secondly, a stimulating effect for a limited numberō of other cell lines. ${ }^{12-15}$ The present work concernso the effects of dexamethasone on the in vitro prolifer $-\overrightarrow{\overrightarrow{0}}$ ation of rabbit articular chondrocytes. Chondro-3 cytes, which maintain the regeneration of cartilaginous tissue by repopulation and reconstruction of the extracellular matrix, are exposed to the anti-थ inflammatory steroids during therapy, as well as the cells implicated in the inflammation process. This: study describes the effects of dexamethasone on chondrocyte growth assessed by analysis of pro-윽 liferation kinetics, including growth curves, cloning efficiency, incorporation of labelled precursors into DNA or RNA, and DNA flow cytometric analysis? Comparisons were made with the fibroblast cell line L 929 sensitive to dexamethasone. Since glucoN corticoid specific receptors have been demonstrated for the chondrocyte in a previous study, ${ }^{16}$ we investigated a possible relation between thew presence of receptors localised at the nuclear leve and the effect of dexamethasone on proliferation

\section{Materials and methods}

CELL CULTURE
Cartilage was taken from the shoulder and knee joints of rabbits (Fauve de Bourgogne) aged 1 to 
months. Chondrocytes were enzymatically released from cartilage slices by Green's method. ${ }^{17}$ Isolated cells were then cultured in HAM F 12 medium supplemented with $10 \%$ fetal calf serum (IBF) containing antibiotics (penicillin $10 \mathrm{IU} / \mathrm{ml}$, streptomycin $10 \mu \mathrm{g} / \mathrm{ml}$ ), and maintained at $37^{\circ} \mathrm{C}$ in an atmosphere of $5 \% \mathrm{CO}_{2}$ in air. When monolayers reached confluence cells were trypsinised in order to obtain the first subculture. Chondrocytes were seeded as described in the text. Fibroblasts L 929 were obtained from the American type culture collection (CCL 1, NCTC clone L 929) and were cultured in minimum essential medium supplemented with $5 \%$ calf serum and the above mentioned antibiotics.

\section{TRE A T M EN T}

One day after seeding the culture medium for each assay was changed and replaced by new medium containing different concentrations of dexamethasone (Sigma).

\section{GROWTH CURVES}

Plastic Petri dishes $(35 \mathrm{~mm})$ were seeded with $7 \times 10^{4}$ cells. After incubation for two, three, four, or six days the cells were removed by trypsinisation, and growth in the absence or presence of dexamethasone was measured at each stage by counting the cells in three dishes using an haemocytometer.

\section{CLONAL GROWTH}

Chondrocyte cultures were trypsinised and single cell suspensions prepared; 200 cells were plated into $35 \mathrm{~mm}$ Petri dishes containing $2 \mathrm{ml}$ of complete medium. After incubation for $24 \mathrm{~h}$ cultures were treated with dexamethasone at the appropriate concentrations, and the clonal plates were incubated undisturbed for eight days at $37^{\circ} \mathrm{C}$ in $5 \% \mathrm{CO}_{2} / 95 \%$ air. The cells were then fixed with absolute methanol and stained with Giemsa (Merck). Plating efficiency was measured in triplicate. In the control and treated Petri dishes the number of clones containing more than 50 cells and the number of clusters containing less than 50 cells were counted separately.

${ }^{3}$ H PRECURSOR INCORPORATION STUDIES Cells were plated in $75 \mathrm{~cm}^{2}$ flasks $\left(5 \times 10^{5}\right.$ cells flask). Twenty four or 48 hours after treatment the cells were incubated for $90 \mathrm{~min}$ in medium containing $\left[{ }^{3} \mathrm{H}\right]$ thymidine $(2 \mu \mathrm{Ci} / \mathrm{ml}(74 \mathrm{kBq} / \mathrm{ml})-10$ $\mathrm{Ci} / \mathrm{mmol}(370 \mathrm{GBq} / \mathrm{mmol})$; CEA 91191 Gif-surYvette Cedex, France) or $\left[{ }^{3} \mathrm{H}\right]$ uridine $(2 \mu \mathrm{Ci} / \mathrm{ml}$ $(74 \mathrm{kBq} / \mathrm{ml})-10 \mathrm{Ci} / \mathrm{mmol}(370 \mathrm{GBq} / \mathrm{mmol}) ; \mathrm{CEA})$, the medium was removed, and each flask washed twice in phosphate buffered saline (PBS). The cells of the substratum were trypsinised, centrifuged, and the supernatant fraction discarded. Cold $0.3 \mathrm{M}$ perchloric acid $(2 \mathrm{ml})$ was added to the cell pellet and maintained in ice for $30 \mathrm{~min}$. After centrifugation and aspiration $0.25 \mathrm{ml}$ of the supernatant (perchloric acid soluble extract) was added to $10 \mathrm{ml}$ of scintillation fluid (Lumagel) for the measurement of the amount of $\left[{ }^{3} \mathrm{H}\right]$ uridine incorporated into RNA. The DNA was then extracted from the pellet (acid insoluble fraction) by $1.2 \mathrm{ml}$ of $1 \mathrm{M}$ perchloric acid $\left(30 \mathrm{~min}\right.$ at $\left.70^{\circ} \mathrm{C}\right) ; 0.25 \mathrm{ml}$ of the supernatant after centrifugation was collected and treated as above for the measurement of the amount of $\left[{ }^{3} \mathrm{H}\right]$ thymidine incorporated into DNA.

For each assay a separate aliquot was used for the measurement of DNA content from each flask by Burton's method. ${ }^{18}$

FLOW CYTOMETRIC ANALYSIS

Cells seeded at $2 \cdot 5 \times 10^{5} / 25 \mathrm{~cm}^{2}$ plastic flask were harvested by trypsinisation after various periods of treatment with dexamethasone. The cells were fixed in $70 \%$ ethanol, treated with ribonuclease, and stained with propidium iodide (Sigma) $(0.05 \mathrm{mg} / \mathrm{ml})$ as described by Crissman and Steinkamp. ${ }^{19}$ Cells (about $5 \times 10^{4}$ ) remaining in the staining solution were analysed in a cytofluorograf (model FC 200/ $4800 \mathrm{~A}$, Ortho Instruments). The relative percentage of cells in $G_{0} G_{1}, S$, and $G_{2}+M$ were estimated according to the method of Fried and Mandel ${ }^{20}$ based on DNA per cell distribution.

NUCLEAR LOCALISATION OF

GLUCOCORTICOID-RECEPTOR COMPLEXES

Cells were seeded in $150 \mathrm{~cm}^{2}$ tissue culture flasks at $3 \times 10^{6}$ cells/flask in $30 \mathrm{ml}$ of complete medium, changed twice weekly.

\section{Labelling}

Experiments were performed after six days of incubation. Four hours before labelling the complete medium was replaced by a serum free medium. All the flasks were treated with various concentrations of $\left[{ }^{3} \mathrm{H}\right]$ dexamethasone $(40 \mathrm{Ci} / \mathrm{mmol}$ (1.48 TBq/mmol), Amersham), and half also received a 1000 -fold excess of non-radioactive dexamethasone (Sigma). At the end of the incubation period $\left(45^{\circ} \mathrm{min}\right.$ at $\left.37^{\circ} \mathrm{C}\right)$ medium was removed to determine free $\left[{ }^{3} \mathrm{H}\right]$ dexamethasone.

\section{Cell and nuclei harvesting}

To each flask was added either $10 \mathrm{ml}$ of PBS free from $\mathrm{Ca}^{2+}$ or $\mathrm{Mg}^{2+}$ or $10 \mathrm{ml}$ of this buffer supplemented with methyl methanethiolsulphonate (MMTS;Sigma), an inhibitor of thiol proteases. After scraping the cells with a rubber policeman. 
flasks were immediately cooled to $0-4^{\circ} \mathrm{C}$. The cells were suspended by dispersion and transferred into cold centrifugation tubes. After centrifugation for five minutes at $800 \mathrm{~g}$ the supernatants were removed, the pellets washed with $10 \mathrm{ml}$ of either PBS or PBS-MMTS, and the suspensions sedimented a second time. The pellets were finally resuspended with $3 \mathrm{ml}$ of PBS or PBS-MMTS. A $1 \mathrm{ml}$ aliquot of these suspensions was used to measure the receptors in the whole cells, and the remaining $2 \mathrm{ml}$ used to measure the nuclear receptors. The following procedure was used for the analysis of whole cells: after centrifugation the supernatants were discarded and $0.55 \mathrm{ml}$ of distilled water was added to the pellets. After $15 \mathrm{~min}$ at $0^{\circ} \mathrm{C}$ (to cell disruption), $250 \mu$ l of the suspension was used for the measurement of cell bound radioactivity and another $250 \mu$ for $\mathrm{DNA}^{18}$ and protein ${ }^{21}$ determinations. For nuclei determina-
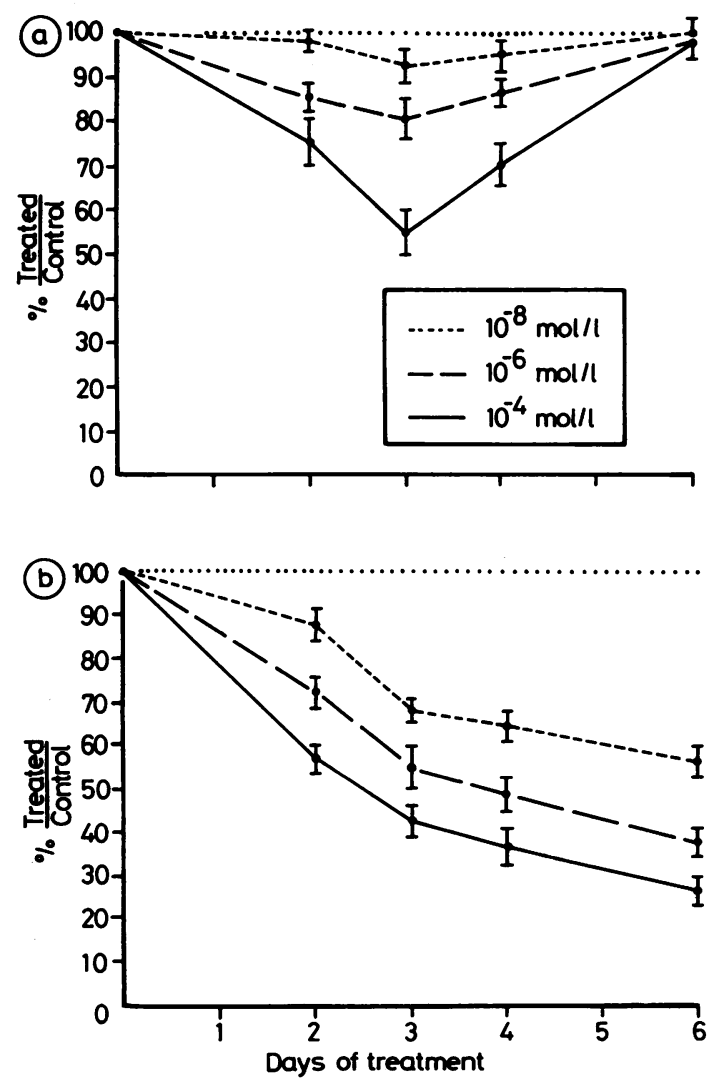

Fig. 1 Time course proliferation of $(a)$ chondrocytes and (b) fibroblasts during treatment for six days with different concentrations of dexamethasone. Numbers of cells are given as percentage values of control cultures. Values are means $(S D)$ of triplicate dishes from three experiments. tions, after centrifugation, the pellets were mixed with $2 \mathrm{ml}$ of STM (sucrose $250 \mathrm{mmol} / \mathrm{l}$; TRIS (trometamol) $50 \mathrm{mmol} / \mathrm{l} ; \mathrm{Mg}^{2+} 5 \mathrm{mmol} / \mathrm{l}, \mathrm{pH} 7.4$ at $\left.4^{\circ} \mathrm{C}\right)$ with or without MMTS $(20 \mathrm{mmol} / \mathrm{l})$, then with $2 \mathrm{ml}$ of the same medium containing $2 \%$ Triton 0 $\mathrm{X}-100$ (Sigma). The mixture was suspended by 30 흐 strokes in a Dounce homogeniser, and cellular lysis was checked by trypan blue exclusion. After centrifugation the crude nuclear pellets were washed with $4 \mathrm{ml}$ of STM or STM-MMTS. Finally, $0.55 \mathrm{ml}$ of distilled water was added to the nuclear pellet and it was treated as described above.

\section{Results}

CELL PROLIFERATION

The effects of dexamethasone at different concen- $N$ trations after various lengths of exposure are indi- $\vec{\sigma}$ cated in Fig. 1a. The maximal inhibition (45 (SD 을 $6) \%$ ) was obtained after three days of treatment at $10^{-4} \mathrm{~mol} / \mathrm{l}$. After this period we observed a plateau T phase in the control chondrocytes, whereas the $\stackrel{D}{\circ}$ treated cells continued to grow at a slower rate, $\frac{c}{D}$ overtaking that of the control cultures at the sixth day (Fig. 2a). Thus as soon as the control chondre $\vec{\theta}$ cytes left the exponential growth phase the inh o bition of proliferation of treated chondrocytes apparently disappeared. In contrast, when the sanie protocol was used with the transformed glucocorticoid sensitive L 929 fibroblasts $^{22-25}$ there was a significant difference in cell behaviour (Figs $1 \mathrm{~b}$ and $\frac{\varnothing}{\varnothing}$ $2 \mathrm{~b})$ : after three days of exposure to the steroid $\left(10^{-8} \propto\right.$ $\mathrm{mol} / \mathrm{l})$ the inhibition of fibroblasts $(30(1.75) \%)$ 흘 was greater than that of chondrocytes $(10(2.5) \%)$ (Figs 1a and 1b). After two days of treatment there was an inhibition of more than $25 \%$ at a dose of $10^{-6}$. $\mathrm{mol} / \mathrm{l}$ for the fibroblasts, whereas the same inhibition was obtained at $10^{-4} \mathrm{~mol} / \mathrm{l}$ with the chondrocytes. A similar difference in sensitivity was also 3 . recorded after three days of treatment. Thus 100 fold less dexamethasone was necessary to obtain the same inhibition with the fibroblasts as with the 0 chondrocytes. Fig. 2b also shows that after three? days the control fibroblasts continued to grow and $\frac{7}{2}$ did not reach a plateau phase as did the chondrocytes; this could explain the observed apparent $\tilde{N}$ increase in inhibition.

\section{CLONAL GROWTH}

Treatment for eight days with different concentrations of dexamethasone showed that at $10^{-4} \mathrm{~mol} / \mathrm{f}$ ? and $10^{-6} \mathrm{~mol} / \mathrm{l}$ it reduced the number of cloneso (Table 1). The lower concentrations of dexamethasone had no significant effect, a result consistents with the observed growth inhibition using the monolayer culture. 
Table 1 Effect of dexamethasone on colony formation

\begin{tabular}{llrll}
\hline $\begin{array}{l}\text { Dexa- } \\
\text { methasone } \\
\text { concentration } \\
\text { (molll) }\end{array}$ & $\begin{array}{l}\text { Number of } \\
\text { clones }\end{array}$ & $\begin{array}{l}\text { Number of } \\
\text { clusters }\end{array}$ & $\begin{array}{l}\text { Plating } \\
\text { efficiency } \\
(\%)\end{array}$ & $\begin{array}{l}\text { Inhibition } \\
(\%)\end{array}$ \\
\hline 0 & $61(4)$ & 7 & $30 \cdot 5$ & - \\
$10^{-4}$ & $35(2 \cdot 5)$ & 16 & 20 & $42 \cdot 5$ \\
$10^{-6}$ & $43(3)$ & 13 & 22 & $29 \cdot 5$ \\
$10^{-8}$ & $59(2 \cdot 5)$ & 7 & $29 \cdot 5$ & - \\
$10^{-10}$ & $60(4)$ & 8 & 30 & - \\
\hline
\end{tabular}

*The results show the mean (SD) number of colonies for five flasks.

Table 2 Effect of $10^{-4}$ molll dexamethasone on the incorporation of $\left[{ }^{3} \mathrm{H}\right]$ thymidine and $\left[{ }^{3} \mathrm{H}\right]$ uridine into chondrocytes after treatment for 24 or 48 hours

\begin{tabular}{lll}
\hline Precursor & \multicolumn{2}{l}{ Incubation period } \\
\cline { 2 - 3 } & $24 \mathrm{~h}$ & $48 \mathrm{~h}$ \\
\hline $\begin{array}{l}\left.{ }^{3} \mathrm{H}\right] \text { Thymidine } \\
\text { [ } \mathrm{H}] \text { Uridine }\end{array}$ & $70(3 \cdot 5)^{*}$ & $77(1 \cdot 5)$ \\
\hline $\begin{array}{l}{ }^{*} \text { Results are the average (SD) of six flasks/group expressed as } \\
\text { a percentage of the control. }\end{array}$
\end{tabular}

\section{DNA AND RNA SYNTHESIS}

Cells incubated for 24 hours with $10^{-4} \mathrm{~mol} / \mathrm{l}$ dexamethasone showed a $30 \%$ decrease in both the amount of $\left[{ }^{3} \mathrm{H}\right]$ thymidine incorporated into DNA and $\left[{ }^{3} \mathrm{H}\right]$ uridine incorporated into RNA, decreasing to $20 \%$ after treatment for 48 hours (Table 2). This was in keeping with the results obtained with the growth curves, except that the onset of inhibition of chondrocyte proliferation was seen after $24 \mathrm{~h}$ rather than between days 2 and 3 .

FLOW CYTOMETRIC ANALYSIS

These experiments showed significant differences in the phase fractions between control and treated cells after treatment for 24 hours (Table 3). With both
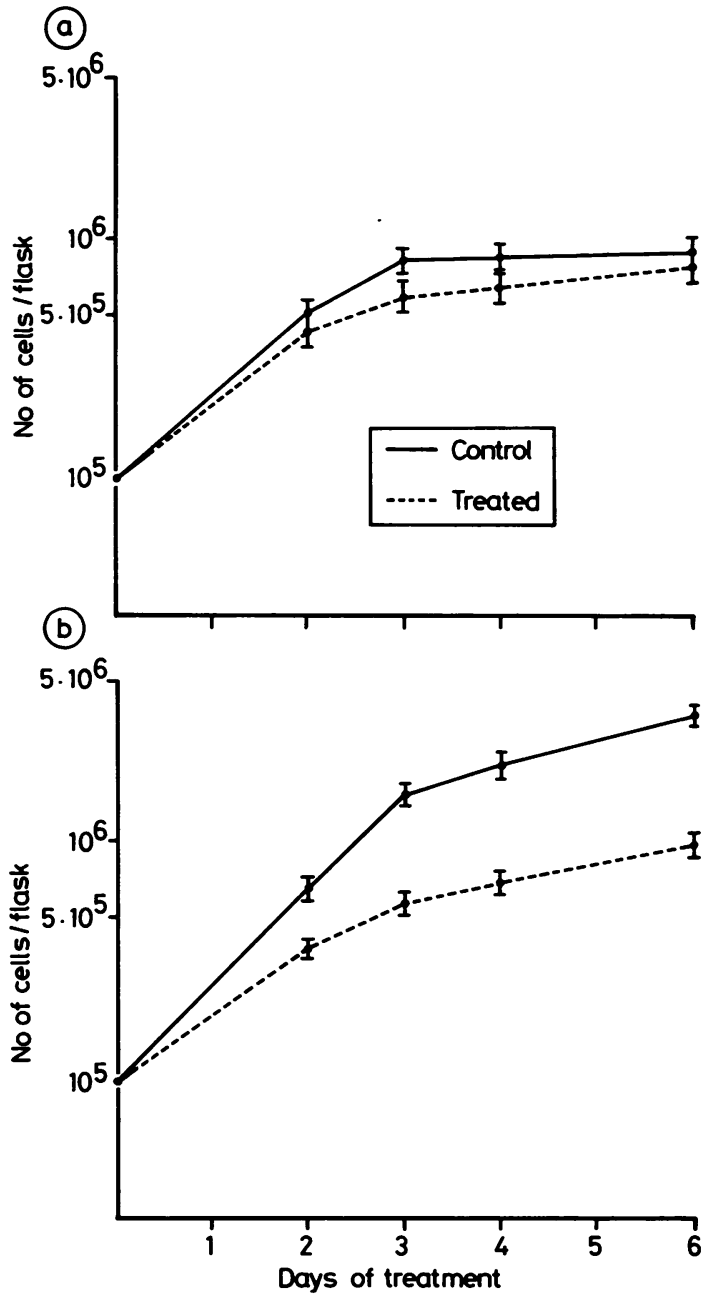

Fig. 2 Growth curve of (a) chondrocytes or (b) fibroblasts cultured for seven days in the presence or absence of $10^{-4}$ molll dexamethasone. Values are means $(S D)$ of triplicate dishes from three separate experiments.

Table 3 Cell cycle analysis based on DNA distribution

\begin{tabular}{|c|c|c|c|c|c|c|c|}
\hline \multirow{3}{*}{$\begin{array}{l}\text { Cellular type } \\
\text { Chondrocytes }\end{array}$} & \multirow{3}{*}{$\begin{array}{l}\begin{array}{l}\text { Dexamethasone } \\
\text { concentration } \\
\text { (molll) }\end{array} \\
0 \\
10^{-4}\end{array}$} & \multicolumn{3}{|l|}{$24 h$} & \multicolumn{3}{|l|}{$48 h$} \\
\hline & & $G_{0} G_{I}$ & $S$ & $G_{2}+M$ & $G_{0} G_{I}$ & $S$ & $G_{2}+M$ \\
\hline & & $\begin{array}{l}46(0 \cdot 5)^{*} \\
58 \cdot 5(2)\end{array}$ & $\begin{array}{l}35(2) \\
24(0 \cdot 5)\end{array}$ & $\begin{array}{ll}19 & (2 \cdot 5) \\
17 \cdot 5(2)\end{array}$ & $\begin{array}{l}71 \quad(1 \cdot 5) \\
75 \cdot 5(3)\end{array}$ & $\begin{array}{l}12(4) \\
10(3)\end{array}$ & $\begin{array}{ll}17 & (3) \\
14 \cdot 5 & (2 \cdot 5)\end{array}$ \\
\hline Fibroblasts & $\begin{array}{l}0 \\
10^{-4}\end{array}$ & $\begin{array}{ll}40 \cdot 5 & (2) \\
56 & (1 \cdot 5)\end{array}$ & $\begin{array}{l}37(4) \\
21(6)\end{array}$ & $\begin{array}{lr}22 \cdot 5 & (6) \\
23 & (6)\end{array}$ & $\begin{array}{ll}53 & (3) \\
65 \cdot 5 & (1)\end{array}$ & $\begin{array}{l}29(5) \\
18(3)\end{array}$ & $\begin{array}{ll}18 & (2) \\
16 \cdot 5 & (1 \cdot 5)\end{array}$ \\
\hline
\end{tabular}

Computed percentages of cells in $G_{0} G_{1}, S$, and $G_{2}+M$ were obtained according to the method of Fried and Mandel. ${ }^{20}$ The model consisted of a phase fraction estimation in which the sum of normal distribution is fitted to the DNA histogram. One distribution approximates the $G_{0} G_{1}$ compartment, one distribution approximates the $G_{2}+M$ compartment, and the remainder approximates the $S$ compartment.

${ }^{*}$ Each value represents the mean (SD) of four measurements and is representative of two separate experiments. 
cell types the treatment caused a diminution in the relative percentage of cells in the $S$ phase and an accumulation of cells in $G_{0} G_{1}$, whereas the $G_{2}+M$ phase was not altered. This accumulation of cells in $\mathrm{G}_{0} \mathrm{G}_{1}$ was maintained for the fibroblasts after exposure to dexamethasone for $48 \mathrm{~h}$, though the control distribution showed a decrease of the $S$ phase in association with an enhancement of $G_{0} G_{1}$ phase. This phenomenon was probably the basis for the slowing of control culture proliferation observed in the growth curves after three days. In contrast with the fibroblasts, the control population of chondrocytes showed a significant arrest in the $\mathrm{G}_{0} \mathrm{G}_{1}$ phase at day 2 . Because the cells were in plateau phase at day 3 it was not possible to detect a dexamethasone induced slowing of the culture proliferation. Thus the inhibitory effects on the proliferation of the chondrocytes and fibroblasts were different.

LOCALISATION OF GLUCOCORTICOIDRECEPTOR COMPLEXES IN RABBIT

ARTICULAR CHONDROCYTES

Specific glucocorticoid receptors have been demonstrated in these two cellular types ${ }^{1625} 26$; we have investigated the possibility that the relative lack of sensitivity of the chondrocytes is associated with a low number of nuclear glucocorticoid-receptor complexes. Preliminary experiments using cells lysed with hypotonic buffer proved difficult to interpret because they produced too many aggregates or nuclei surrounded by cell fragments. Therefore Triton $\mathrm{X}-100$, a neutral detergent, was used. This produced good cell lysis and particularly 'clean' nuclei. Kaufmann et al reported that, owing to the lability of nuclear complexes during cellular fractionation and nuclear isolation, techniques using detergent need to be performed under conditions which included the presence of sulphydryl blocking reagents, such as MMTS. ${ }^{27}$ Using medium contain-

Table 4 Influence of MMTS on the stability of the nuclear dexamethasone-receptor complex in chondrocytes

\begin{tabular}{|c|c|c|c|c|}
\hline \multirow[t]{2}{*}{ Sample } & \multicolumn{2}{|c|}{ No treatment } & \multicolumn{2}{|c|}{ With MMTS } \\
\hline & $\begin{array}{l}c p m / \mu g \\
D N A\end{array}$ & $\begin{array}{l}\text { Nuclear } \\
\text { sites }(\%)\end{array}$ & $\begin{array}{l}c p m / \mu g \\
D N A\end{array}$ & $\begin{array}{l}\text { Nuclear } \\
\text { sites (\%) }\end{array}$ \\
\hline $\begin{array}{l}\text { Whole cells } \\
\text { Nuclei }\end{array}$ & $\begin{array}{l}76(7)^{*} \\
19(5)\end{array}$ & 25 & $\begin{array}{l}84(8) \\
58(5)\end{array}$ & 69 \\
\hline
\end{tabular}

Tissue culture flasks $\left(150 \mathrm{~cm}^{2}\right)$ were incubated for $45 \mathrm{~min}$ at $37^{\circ} \mathrm{C}$ in serum free medium (HAM F 12) containing $20 \mathrm{nmol} / \mathrm{l}$ $\left[{ }^{3} \mathrm{H}\right]$ dexamethasone. For further details see Materials and methods'.

${ }^{*}$ Values are the mean (SD) from three results.

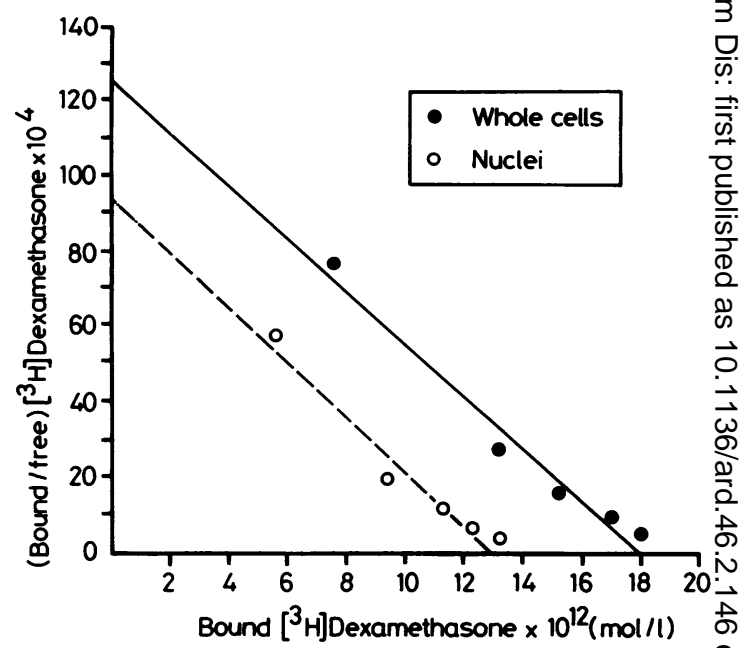

Fig. 3 Scatchard analysis of specific $\left[{ }^{3} \mathrm{H}\right]$ dexamethasone $\mathrm{O}$ binding to whole cells and nuclei at various glucocorticoid $\vec{T}$ concentrations in a typical experiment using MMTS. The apparent affinity, $K_{D}=1.4 \times 10^{-9}$ molll. Bmax (cellular) $=4 \cdot 1 \mathrm{fmol} / \mu \mathrm{g} D N A=26500$ binding sites $/ \mathrm{cell}$ $(r=-0.98) ; B \max ($ nuclear $)=2.9 \mathrm{fmol} / \mathrm{\mu g} D N A=19100$ binding sites/cell $(r=-0.97)$; nuclear sites $=72 \%$.

ing MMTS we demonstrated (Table 4) the localisa tion of the activated complex in the nucleus of rabbio articular chondrocyte $(69 \%$ v $25 \%$ nuclear sites $) \stackrel{\%}{2}$ The number of sites (Bmax) and the apparen $\$$ affinity $\left(\mathrm{K}_{\mathrm{D}}\right)$, both for the whole cells and the nucles (Fig. 3), were calculated by Scatchard analysis. $\frac{2}{3}$ The $K_{D}$ values were identical for whole cells anథ nuclei.

\section{Discussion}

These results show that concentrations of dexa methasone in the range of $10^{-6}$ to $10^{-4} \mathrm{~mol} / \mathrm{s}$ inhibited cell growth of chondrocytes in a dose an® time dependent manner. This inhibition was als@ observed using a DNA precursor or determinatio of the percentage of $S$ cells by flow cytometry. The inhibition of RNA synthesis is in accordance wit席 other reports that dexamethasone acts also on metabolic systems other than DNA. ${ }^{29-31}$ In ourv experimental conditions, however, the chondrocytess were not particularly sensitive to this glucocorticoigs since significant growth inhibition was only observed at $10^{-4} \mathrm{~mol} / \mathrm{l}$. This was previously described by Ronot et al with another glucocorticoid druge methylprednisolone..$^{32}$. Comparison of these inhibitory effects on chondrocytes with those observed $o \bar{B}$ L 929 fibroblasts or other cell types ${ }^{59} 9334$ ind cates that treatment with dexamethasone for iderfôे 
tical times and doses was less effective on the cartilaginous cell. Since chondrocytes have been shown to exhibit specific functions and good proliferation capacity, ${ }^{35}$ the lack of sensitivity of these cells to glucocorticoids compared with other cell types involved in the inflammatory process is probably not due to the culture conditions.

We have confirmed the observation of Blondelon et $a^{16}$ that rabbit articular chondrocytes in culture are a target cell for glucocorticoids, i.e., subject to hormonal control. Indeed the glucocorticoidreceptor complexes were able to undergo activation and transformation resulting in an effect at the genome level because the majority became localised in the nucleus. In view of the discrepancy between the dose of dexamethasone responsible for $50 \%$ inhibition $\left(10^{-4} \mathrm{~mol} / \mathrm{l}\right)$ and the $K_{D}$ value $(1.4$ (SD $\left.0 \cdot 2) \times 10^{-9} \mathrm{~mol} / \mathrm{l}\right)$ it seems that inhibitory action on proliferation cannot be explained exclusively by binding to glucocorticoid receptors. These results are therefore in contrast with many studies that have shown a correlation between the presence of specific glucocorticoid binding of these molecules and growth inhibition for various cell types. ${ }^{2} 4936-38 \mathrm{On}$ the other hand, it has been shown that resistance to glucocorticoids is often associated with a decrease in receptor activity 2233 or sometimes with a defect in the translocation process. ${ }^{40}$ The data presented here indicate that the dexamethasone induced growth inhibition of chondrocytes does not involve solely a glucocorticoid effect mediated by specific receptors. This result is in accordance with that of Keller $e t$ al, who described evidence for more than one mechanism of action of glucocorticoids. ${ }^{41}$ Our work suggests that there are at least two different mechanisms involved in the inhibition of chondrocyte proliferation by glucorticoids. In addition to a direct control of a small amplitude, in which the receptors are involved, there is also a strong inhibitory effect at high concentrations, probably the consequence of several metabolic inhibitions (metabolism of sugars, amino acids, etc) due to the glucocorticoids, and which results in a decrease of cellular activity.

\section{References}

1 Silbermann M. Kadar T. Quantitative changes in the cellular population of the growth plate of triamcinolone treated mice. Acta Anat (Basel) 1977: 98: 396-400.

2 Chen T L. Aronow L. Feldman D. Glucocorticoid receptors and inhibition of bone cell growth in primary culture. Endocrinology 1977: 100: 619-28.

3 Grasso R J, Tedesco T A. Wodzinski S F, Johnson C E. Temporal relationships between DNA metabolism and the growth inhibitory response produced by dexamethasone in rat glioma cell cultures. In Vitro 1978: 14: 625-30.

4 Verbruggen L A. Salomon D S. Glucocorticoid receptors and inhibition of neonatal mouse dermal fibroblast growth in primary culture. Arch Dermatol Res 1980; 269: 111-26.

5 Ponec M. De Kloet E R, Kempenaar J A. Corticoids and human skin fibroblasts: intracellular specific binding in relation to growth inhibition. J Invest Dermatol 1980: 75: 293-6.

6 Horn D, Buzard R L. Growth inhibition by glucocorticoids in RPMI 3460 melanoma cells. Cancer Res 1981; 41: 3155-60.

7 Borthwick N M. Bell P A. Temporal relationships between inhibitory effects of glucocorticoids on cells of the CEM-C7 human leukaemic lymphoblast cell line. Eur J Cancer Clin Oncol 1982; 18: 1093-8.

8 Smets L A, Bout B, Brouwer M. Tulp A. Cytotoxic effects of dexamethasone restricted to non cycling early $G_{1}$ phase cells of L1210 leukemia. J Cell Physiol 1983; 116: 397-403.

9 Ranelletti F O, Starace G. Piantelli M, Lambertenghi-Deliliers G, Revoltella R P. Glucocorticoid receptors and corticosensitivity in a human clonal monocytic cell line, CM-SM. J Cell Physiol 1983; 116: 329-35.

10 Hamilton J A. Glucocorticoids and prostaglandins inhibit the induction of macrophage DNA synthesis by macrophage growth factor and phorbol ester. J Cell Physiol 1983; 115: 67-74.

11 Silbermann M. Maor G. Receptor mediated glucocorticoid inhibition of cell proliferation in mouse growth cartilage in vitro. Acta Endrocrinol 1985; 108: 343-50.

12 Runikis J O. McLean D I. Stewart W D. Growth rate of cultured human fibroblasts increased by glucocorticoids. J Invest Dermatol 1978: 70: 348-51.

13 Gaffney E V. Pigott D. Hydrocortisone stimulation of human mammary epithelial cells. In Vitro 1978: 14: 621-4.

14 Guerriero V. Florini J R. Dexamethasone effects on myoblast proliferation and differentiation. Endocrinology 1980; 106: 1198-202.

15 Kondo H. Kasuga $H$, Noumura T. Effects of various steroids on in vitro lifespan and cell growth of human fetal lung fibroblasts (WI 38). Mech Ageing Dev 1983: 21: 335-44.

16 Blondelon D. Adolphe M. Zizine L. Lechat P. Evidence for glucocorticoid receptors in cultured rabbit articular chondrocytes. FEBS Lett 1980; 117: 195-8.

17 Green W T. Behaviour of articular chondrocytes in cell culture. Clin Orthop 1971: 75: 248-60.

18 Burton K. A study of the conditions and mechanism of the diphenylamine reaction for the colorimetric estimation of deoxyribonucleic acid. Biochem J 1956; 62: 315-23.

19 Crissman H A. Steinkamp J A. Rapid simultaneous measurement of DNA. Protein and cell volume in single cells from large mammalian cell populations. J Cell Biol 1973: 59: 766-71.

20 Fried J. Mandel M. Multi-user system for analysis of data from flow cytometry. Comput Programs Biomed 1979: 10: 218-30.

21 Lowry O H. Rosebrough N J. Farr A L. Randall R J. Protein measurement with the folin phenol reagent. J Biol Chem 1951: 193: 265-75.

22 Hackney J F. Gross S R. Aronow L. Pratt W B. Specific glucocorticoid-binding macromolecules from mouse fibroblasts in vitro. A possible steroid receptor for growth inhibition. Mol Pharmacol 1970; 6: 500-12.

23 Middlebrook J L. Wong M D. Ishii D N. Aronow L. Subcellular distribution of glucocorticoid receptors in mousc fibroblasts. Biochemistry 1975: 14: 180-6.

24 Ponec M. De Haas C. Bachra B N. Polano M K. Effects of glucocorticosteroids on primary human skin fibroblasts. Arch Dermatol Res 1977: 259: 117-23.

25 Aronow L. The glucocorticoid receptor of mouse fibroblast. Fed Proc 1978: 37: 162-6.

26 Pratt W B. Kaine J L. Pratt D V. The kinetics of glucocorticoid binding to the soluble specific binding protein of mouse fibroblasts. J Biol Chem 1975; 250: 4584-91.

27 Kaufmann S H. Quddus F F. Shaper J H. An alternative approach to the quantitation of glucocorticoid-receptor complexes in the nuclei of lymphoid cells. Endocrinology 1982; 110: 708-16. 
28 Scatchard G. The attractions of proteins for small molecules and ions. Ann NY Acad Sci 1949: 660-72.

29 Cutroneo K R, Rokowski R. Counts D F. Glucocorticoids and collagen synthesis: comparison of in vivo and cell culture studies. Coll Relat Res 1981; 1: 557-68.

30 Pinnell S R. Regulation of collagen synthesis. J Invest Dermatol 1982; 79 (suppl 1): 73-6s.

31 Sterling K M, Harris M J, Mitchell J J, Dipetrillo T A, Delaney G L, Cutroneo K R. Dexamethasone decreases the amounts of type 1 procollagen mRNAs in vivo and in fibroblast cell cultures. J Biol Chem 1983; 258: 7644-7.

32 Ronot X, Blondelon D. Perret C, Adolphe M, Fontagne J. Lechat $P$. Effects of high doses of methylprednisolone on rabbit articular chondrocytes in culture. Int J Tissue React 1980; 2: 145-50.

33 Bourgeois S, Newby R F. Correlation between glucocorticoid receptor and cytolytic response of murine lymphoid cell lines. Cancer Res 1979: 39: 4749-51.

34 Smith K A. Crabtree G R, Gillis S, Munck A. Glucocorticoid control of $T$ cell proliferation. In: lacobelli $S$, King $R$ J B. Lindner H R, Lippman M E. Hormones and cancer. New York: Raven, 1980: 125-34. (Progress in cancer research and therapy: Vol 14).
35 Adolphe M, Froger B, Ronot X, Corvol M T. Forest N. Cell multiplication and type II collagen production by rabbit articular chondrocytes cultivated in a defined medium. Exp Cell Res 1984; 155: 527-36.

36 Bhakoo H S, Paolini N S, Milholland R J, Lopez R E, Rosen F. Glucocorticoid receptors and the effect of glucocorticoids on the growth of B 16 melanoma. Cancer Res 1981; 41: 1695-701.

37 Kubota K, Kubota R, Matsuzawa T. Dose-responsive growth $\frac{\bar{\rho}}{\partial}$ inhibition by glucocorticoid and its receptors in mouse terato- $\mathbb{D}$ carcinoma OTT 6050 in vivo. Cancer Res 1983; 43: 787-93.

38 Osman A M, Jansen P W M, Smets L A, Benckhvijsen C. C) Glucocorticoid receptors and cell cycle progression in human $\vec{\circ}$ melanoma cell lines. J Cell Physiol 1985; 125: 306-12.

39 Sibley $\mathrm{C} \mathrm{H}$, Tomkins G M. Mechanisms of steroid resistance. Cell 1974; 2: 221-7.

40 Holbrook N J, Cox W I, Hackney J F, Grasso R. Glucocorticoid-resistant glioma cells that contain cytosolic receptors. Proc Soc Exp Biol Med 1980; 180: 235-41.

41 Keller B T, Landes G M, Kitos P A. Evidence for more than one mechanism of action of the glucocorticoid hormones. $A$ Biochim Biophys Acta 1982; 717: 228-35. 